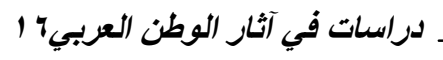

\title{
Deceased receives New Year Gifts in Theban Private Tombs
}

\section{Ahmed Ebied ${ }^{\bullet}$}

\section{Abstract:}

The Theban necropolis is located on the western bank of Thebes, covering an area about 5.5 square miles and it contains not only tomb but also some temple, chapels and palaces. Scenes depicting the deceased receive New Year gifts are in various parts of the Theban private tombs, like Sheikh Abd el-Qurna, El-Khokha.

One can wonder why more of these scenes are found in the tombs of individuals at New Kingdom period? The answer is surely not unambiguous. It is probable that the owner of tomb whose functions have a relationship with royal worship, and which did depend economically on a temple of million years, felt less concerned. Maybe he also questioned a sovereign's will to which nothing special had connected him to serve him as an intercessor with the gods?

The New Year gifts appears in figures of many and different type in the New Kingdom private tombs at Thebes. The Categories of these figures or scenes are presented by Porter and Moss. ${ }^{1}$ All the scenes depicted the New Year gifts before deceased and his wife, or from wife and all of the family, or from a person. This paper hopes to build on that by taking the case of representations of deceased receives New Year gifts, and discussing what they may tell us about the role of the deceased in the lives of the people.

This paper will display these entire scenes with the aim of showing if certain scenes were restricted to certain parts of the tombs and also it will be conducted by displaying the scenes in tables, the numbers that I give number ' 1 ' to each scene not like P. M Numbers.

The research question is: If the New Year gift scenes have been represented in the same area and what does it means? And, the main question is: Who was giving this New Year gifts to the deceased or the owner of the tombs? Why?

Key words: Deceased, New Kingdom, New Year gifts, New Year Festival, Private Tombs, Thebes.

\footnotetext{
- South Valley University, Egypt, 2014
}

1 P. M, I, p. 472, no. 33. 


\section{Introduction:}

The $18^{\text {th }}$ dynasty of ancient Egypt is the best known of all the dynasties of ancient Egypt. It may have started a few years earlier than the conventional date of $1550 \mathrm{BC}$. The radiocarbon date range for its beginning is $1570-1544 \mathrm{BC}$, the mean point of which is $1557 \mathrm{BC}{ }^{2}$ or ca. $1550-1069$ BC. ${ }^{3}$

It is an interesting period in ancient Egyptian history. The preceding $2^{\text {nd }}$ intermediate period was dominated by internal quarrels but is mostly remember for its Hyksos dominated. ${ }^{4}$ Egypt was reunited in the last decade of the reign of Ahmose, who defeated the Hyksos, becoming the $1^{\text {st }}$ king of the $18^{\text {th }}$ dynasty. ${ }^{5}$ The initial aversion towards outsiders, following from this period of foreign domination, didn't last very long, and the New Kingdom soon prospered through international contacts and exchange (combined with military incursions into Near East) in the $2^{\text {nd }}$ half of the $18^{\text {th }}$ dynasty.

The most famous thing in this dynasty is the reformation of the Egyptian religion of king Akhenaten, who denounced gods except Aten, and this monotheistic concept was quickly rejected after his death.

The New Year gifts were very important issue in ancient Egyptian private tomb especially in Theban private tombs.

The $1^{\text {st }}$ appearance was from the Middle kingdom, we can't found any scenes before the time of the New kingdom except one scene in (TT. $60)^{6}$ of Intefiqer, ${ }^{7}$ at Sheikh Abd el-Quanah. ${ }^{8}$

${ }^{2}$ Bronk Ramsey, C., et al., Radiocarbon-Based Chronology for Dynastic Egypt, Science 18 June 2010, vol. 328, no. 5985, pp. 1554- 1557.

${ }^{3}$ Shaw, I., The Oxford History of Ancient Egypt, Oxford University Press, Oxford, 2000.

${ }^{4}$ Bourrian, J., The Second Intermediate Period, In, The Oxford History of Ancient Egypt, Shaw, I., (ed.) Oxford University Press, 2000, pp. 185- 186.

${ }^{5}$ Bryan, B., The Eighteenth Dynasty before The Amarna Period (c. 1550- 1352 BC), In, The Oxford History of Ancient Egypt, Shaw, I., (ed.) Oxford University Press, 2000, p. 218.

${ }^{6}$ This tomb for him and his mother Sent 'Prophetess of Hathor', P. M, I, p. 121

7 Ranke, H., Die Ägyptische Persönennamen, Verlag von J. J. Augustin in Glückstadt, 1935, p. 34; Intefiqer was overseer of the city and vizier under Amenemhat I and Senwosret I during the $12^{\text {th }}$ dynasty. He appears in an inscription found at the Red Sea coast and in the so-called Reisner Papyri. Two rock inscriptions in Lower Nubia mention him. They seem to indicate that he was involved in a military campaign into this region, See, Zaba, Z., The Rock Inscriptions of Lower Nubia, Prague 1974, p. 39 (no. 10), 99, (no. 73); The inscriptions are not dated, but other inscriptions in the region seem to indicate a military campaign in year 29 of Amenemhat I, which was the $9^{\text {th }}$ year of Senwosret I. Intefiqer is= =also known from a stela found at Wadi el-Hudi, dated to year 20. It reports the bringing of 


\section{New Year gifts before deceased and his wife:}

\subsection{Tomb of Intefiqer, ${ }^{9}$ Sheikh Abd el-Qurna, $12^{\text {th }}$ dynasty (TT. 60): $:^{10}$}

He was overseer of the city and vizier under Amenemhat I and Senwosret I during the $12^{\text {th }}$ dynasty. ${ }^{11}$ This tomb also for his mother Sent 'Prophetess of Hathor'

Intefiqer appear in his tomb approaching the throne of king Sesostris $\mathrm{I}^{12}$ (too lost), apparently by intent as the line of fracture closely follows that of the body and a small part of the feather attached to the side of the white

Amethyst, See, Sadek, A. I., The Amethyst Mining Inscriptions I, Text, Warminster 1980, pp. 22-24 (no. 8); The tomb of his mother (or wife) Senet in Thebes is in Sheikh Abd el-Qurna in the Theban Necropolis, opposite Luxor, See, Baikie, J., Egyptian Antiquities in the Nile Valley, Methuen, 1932, p. 575; Intefiqer was buried in a Mastaba at Lisht, next to the pyramid of Amenemhet I, See, Arnold, D., Middle Kingdom Tomb Architecture at Lisht, New York 2008, pp. 6971, pls. 62- 92, pl. 129- 133.

${ }^{8}$ Buchberger, H., Das Harfnerlied im Grab des $K 3$ (=i)-m- ${ }^{-} n h$ oder "Die Riten des sn ntrw", In, Fs Barta, 1995, pp. 93- 124. Polz, D., Bemerkungen der Grabbenutzung in der thebanischen Nekropole, MDAIK, 46, 1990, pp. 301- 336.

9 Ranke, H., Die Ägyptische Persönennamen, Verlag von J. J. Augustin in Glückstadt, 1935 , p. 34

${ }_{10}$ Buchberger, H., Das Harfnerlied im Grab des K3 (=i)-m-anh oder "Die Riten des sn ntrw", In, Fs Barta, 1995, pp. 93- 124. Polz, D., Bemerkungen der Grabbenutzung in der thebanischen Nekropole, MDAIK, 46, 1990, pp. 301- 336.

${ }^{11} \mathrm{He}$ appears in an inscription found at the Red Sea coast and in the so-called Reisner Papyri. Two rock inscriptions in Lower Nubia mention him. They seem to indicate that he was involved in a military campaign into this region, See, Zaba, Z., The Rock Inscriptions of Lower Nubia, Prague 1974, p. 39 (no. 10), 99, (no. 73); The inscriptions are not dated, but other inscriptions in the region seem to indicate a military campaign in year 29 of Amenemhat I, which was the $9^{\text {th }}$ year of Senwosret I. Intefiqer is also known from a stela found at Wadi el-Hudi, dated to year 20. It reports the bringing of Amethyst, See, Sadek, A. I., The Amethyst Mining Inscriptions I, Text, Warminster 1980, pp. 22-24 (no. 8); The tomb of his mother (or wife) Senet in Thebes is in Sheikh Abd el-Qurna in the Theban Necropolis, opposite Luxor, See, Baikie, J., Egyptian Antiquities in the Nile Valley, Methuen, 1932, p. 575; Intefiqer was buried in a Mastaba at Lisht, next to the pyramid of Amenemhet I, See, Arnold, D., Middle Kingdom Tomb Architecture at Lisht, New York 2008, pp. 69- 71, pls. 62- 92, pl. 129- 133.

${ }^{12}$ P. M, I, p. 121 (3). 
crown which the king wears. ${ }^{13}$ Davies proposes therefore that this scene has been imagined by the vizier as an exaltation of his function, which he wanted to represent at a precise date, the one of his sovereign's Jubilee.

On the passage of the tomb, there is a scene for the deceased and his wives inspect four registers of New Year gifts. ${ }^{14}$ On the first three registers there are vases and jewelry while the fourth register having Geese, Crane, Calf, and bull. (Fig. 3)

The gifts in question, which it was usual to offer at the time of certain festivals, are essentially those from the craft industry. This is why the prayers are addressed from the dual divinity Ptah-Sokar.

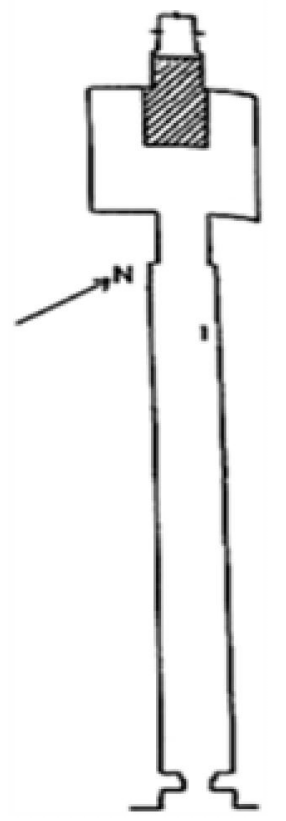

Plan of Intefiqer tomb, Sheikh Abd el-Qurna (TT. 60)

P. M, I, p. 106

Above the couple is an inscription in two lines: "Seeing the gifts the day of the Festival of the New Year, coming from his domain, all manner of silver, carnelian, lapis lazuli and turquoise, all good things in great quantity, for the noble, the royal child (or god-child?), superintendent of the city, The one of the curtain, superintendent of the Six Great Courts, Intefiqer, justified (and for) his wife, whom he loves, the priestess of Hathor, 'Sitsisobk', the fully revered".

All of the gifts are for the couple, Intefiqer and his wife 'Sitsisobk', who are shown in standing position. This is surmounted by a line of text (now very faint): "For your kas, oil of myrrh, which Ptah mixed, which the Lady of Punt transported, which the director of the Necropolis refined and which Sokar liquefied with

${ }^{13}$ Davies, Norman de Garis, The Tomb of Antefoker, Vizier of Sesostris I and of His Wife, Senet (No. 60), TTS, 2, London: EES, 1920, p. 18, pl. xvi.

14 P. M, I, p. 122 (11); Davies, Norman de Garis, The Tomb of Antefoker, Vizier of Sesostris I and of His Wife, Senet (No. 60), TTS, 2, London: EES, 1920, p. 17, pl. xiv 
its fingers ${ }^{15}$ - Silver, gold, lapis lazuli, turquoise, carnelian, (bi3.t) and all kinds of true precious stones from the house of Osiris". ${ }^{16}$

There are also, two women, and behind them, resting on the jewelry chest of the vizier, is a somewhat oversized hieroglyphic sign for gold, in shape of a necklace. A servant, possibly Intefiqer servant, brings a small casket; maybe this is the actual one, in real size, of the extremely large version shown in front. Next is a large chest, on which are piled weapons and bows, whose representation is partially lost, but the two shields and curves and twisted ropes of the bows, can still be recognized. (Figs. 4, 5)

Above are two quivers of six arrows and two slings. Lying on the very top is the same scepter which the vizier holds in his right hand in the next zone. And finally, ending the procession, two men carry the materials of a scribe, the large container of the first being a cylinder holding rolls of papyrus.

\subsection{Tomb of Puimre, El-Khokha, Thutmose III, $18^{\text {th }}$ dynasty (TT. 39):}

Puimre was an ancient Egyptian noble and architect and the $2^{\text {nd }}$ prophet of Amun during the reigns of Hatshepsut and Thutmose III. ${ }^{18}$

Plan of Puimre tomb, El-Khokha (TT. 39)

$$
\text { P. M, I, p. } 64
$$

On the south chapel of Puimre tomb, there is a

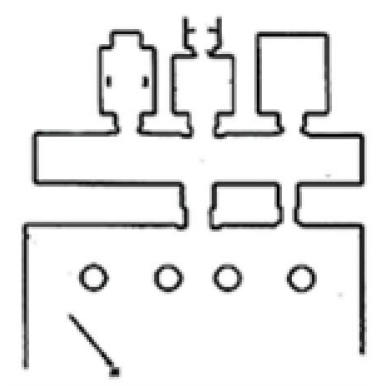

${ }^{15}$ Read m Dbaw.f.

${ }^{16}$ Davies, Norman de Garis, The Tomb of Antefoker, Vizier of Sesostris I and of His Wife, Senet (No. 60), TTS, 2, London: EES, 1920, p. 16.

17 Gardiner, A., and Weigall, A., A Topographical Catalogue of the Private Tombs of Thebes, London: Quaritch, 1913, pp. 18- 19; Kampp, F., Die Thebanische Nekropole. Zum Wandel des Grabgedankens von der XVIII. bis zur XX. Dynastie, Theben, 13,vol. I, Mainz am Rhein: Verlag Philipp von Zabern, 1996, pp.. 230- 233, figs.130- 132; Wasmuth, M., Innovation und Extravaganzen: Ein Beitrag zur Architektur des thebanischen Beamtengräber der 18. Dynastie, BAR International Series, 1165, Oxford: British Archaeological Reports, 2003, p. 83.

18 P. M, I, p. 71; http://www.uvmnet.edu/investigacion/episteme/numero405/colaboracion/a preliminary.asp 12/9/2013 
scene in (right and left hand side wall) for the sons and daughters of the deceased with New Year gifts before him and his wife (Sensonb on left wall, Tanefert on right wall) (figs. 1, 2). ${ }^{19}$ This familiar scene represent; the figures of the deceased before the table of bread and the pile of varied provisions, the tabulated list of offerings, and the list of food, drinks and materials for ritual is an abbreviation of the longer list.

\subsection{Tomb of Amenhotep, Sheikh Abd el-Qurna, Thutmose I, $18^{\text {th }}$ dynasty (TT. 345):}

Amenhotep was $w^{c} b$ priest, and eldest King's son of Thutmose I. On the hall of his tomb, there is a scene for him with his wife 'Renay' receiving New Year gifts at festival of Nehebkau, ${ }^{20}$ with girl offering to them and there are three registers; ${ }^{21}$ female musicians and female guests, female clappers and male guests, and harpist and male guests.

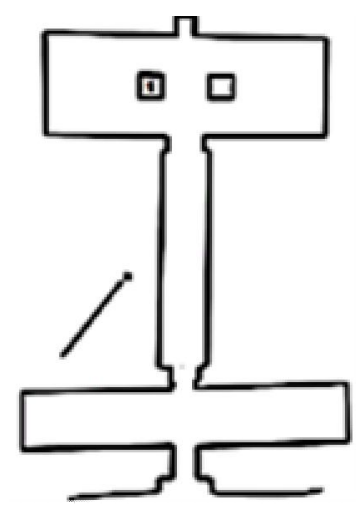

Plan of Amenhotep tomb, Sheikh Abd el-Qurna (TT. 345)

P. M, I, p. 400

19 P. M, I, p. 73 (14- 15); Davies, Norman de Garis, The Tomb of Puyemrê at Thebes, II, The chapels of hope, New York, 1923, pp. 30- 31, pl. lviii

His wife Sensonb was the daughter of the high priest of Amun 'Hapuseneb' and his wife 'Amenhotep'. She served in the temple of Amun as a Divine Adoratrix, See, O'Connor, David and Cline, Eric H. Thutmose III: A New Biography University of Michigan Press. 2006.

${ }^{20}$ God who joined the $\mathrm{Ka}$ to the Body, and God of Protection and Magic

${ }^{21}$ P. M, I, p. 414 (5) 


\subsection{Tomb of Na'amutnakht, Sheikh Abd el-Qurna, $22^{\text {nd }}$ dynasty, $18^{\text {th }}$ dynasty (TT. 348):}

We don't know the real owner of this tomb but he was a chief steward, unique friend and a mayor during the $18^{\text {th }}$ dynasty and $\mathrm{Na}$ 'amutnakht usurped this tomb. He was door-opener of the gold house of Amun, and chief gardener of the Ramessseum. ${ }^{22}$

Plan of Na'amutnakht tomb, Sheikh Abd el-Qurna (TT. 348)

$$
\text { P. M, I, p. } 400
$$

On the court of the tomb, there is a scene for the

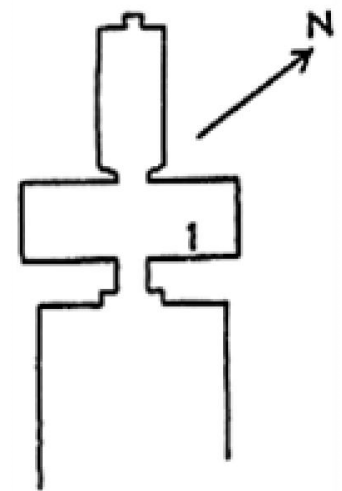
original owner of the tomb with his wife receives [New Year gifts].

\section{New Year gifts from wife and all of the family to the deceased:}

2.1 Tomb of Senneferi, ${ }^{23}$ Sheikh Abd el-Qurna, Tuthmosis III (TT. 99): ${ }^{24}$

He was overseer of the seal and "overseer of the gold-land of Amun". ${ }^{25}$ On the pillar of the passage, there is a scene for the owner of the

${ }^{22}$ P. M, I, p. 415

${ }^{23}$ Gutbub, A., Sennefer, LÄ, V, 856- 857.

Senneferi seems to have been related to Amenhotep, the owner of Tomb C.3, because he is mentioned in lost tomb C.3 and a statue of Amenhotep was found in TT. 99, Piehl, K., Inscriptions hiéroglyphiques I, Stockholm- Leipzig, 1886, CXLII (X), CXLIII (Z), with a sketch plan in $i d$., Inscriptions hiéroglyphiques II, Stockholm-Leipzig, 1888, p. 111.

${ }^{24}$ Mond, R., Report on Work Done in the Gebel esh-Sheikh Abd el-Kurneh at Thebes, January to March, 1903, ASAE, 5, 1904, pp. 101- 102; Mond, R., Report of Work in the Necropolis of Thebes during the Winter of 1903-1904, ASAE, 6, 1905, p. 87; Navrátilová, H., Sennefer. In: Thebes: City of Gods and Pharaohs, Mynářová. J., and Pavel, O., Prague: Národní Muzeum, 2007, pp. 129- 132; Strudwick, N., The Theban Tomb of Senneferi: An Overview of Work Undertaken from 1992 to 1999, Memnonia, 11, 2000, pp. 241- 266; Strudwick, N., Theban Tomb 99 (Senneferi): University of Cambridge Theban Mission 2002, ASAE, 79, 2005, pp. 157- 164.

${ }^{25}$ Rice, M., Who's Who in Ancient Egypt, Rout-ledge, 1999, p. 183. 
tomb receives New Year gifts from his wife and all of his family with remains of texts. ${ }^{26}$ (Figs. 6, 7)

Plan of Senneferi tomb, Sheikh Abd el-Qurna (TT. 99)

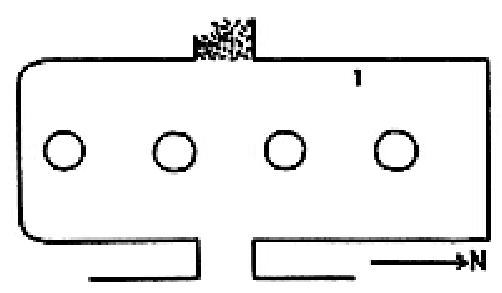
P. M, I, p. 196

Seeing the greetings brought by his wife, children, brothers, and craftsmen on the day of the New Year festival and the Neheb-kau festival, on the day of the $1^{\text {st }}$ of the year, the appearing of Sopdet, by the iry pat, $h^{\top} t y$ ', the beloved semer, the official to whom the heart is opened, one great of praise in the house of the king, who reaches old age excellently in that office, the mouth which holds forth in the whole land, the overseer of seal bearers [Senneferi, justified]. ${ }^{27}$

\section{New Year gifts from a person to the deceased:}

\subsection{Tomb of Mentiywy, El-Khokha, Tuthmosis III- Amenhotep II (TT. 172): ${ }^{28}$}

He was royal butler, and child of the nursery. There is a scene on the passage of the tomb for Mentiywy with a man offering collars as New Year gifts to him. $^{29}$

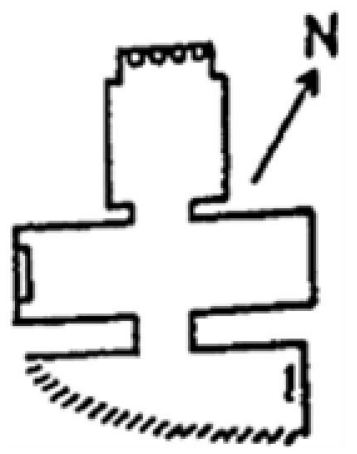

Plan of Mentiywy tomb, El-Khokha (TT. 172)

P. M, I, p. 272

\footnotetext{
${ }^{26}$ P. M, I, p. 205 (A).

${ }^{27} \mathrm{http}$ ://www.fitzmuseum.cam.ac.uk/tt99/paintings/pillarAE.html 17/9/2013

28 MacKay, E., Report of the Excavations and Other Works Carried out in the Necropolis of Thebes, ASAE, 14, 1914, p. 93.

${ }^{29}$ P. M, I, p. $280(9)$
} 


\section{Other New Year gifts:}

\subsection{Tomb of Amenhotep, Sheikh Abd el-Qurna, Hatshepsut (TT. 73):}

He was the chief steward, overseer of the works on the two great obelisks in the temple of Amun, and veteran of the king. The name of the owner of the tomb was erased. ${ }^{30}$ Habachi suggest the name as Amenhotep. ${ }^{31}$ There are two scenes for the deceased; ${ }^{32}$ deceased inspects four registers; new year gifts for the temple of Amun including royal statuettes (Hatshepsut kneeling between Sekhmet and Amun), Saits nursing young Hatshepsut with Amun, and Thoth writing with Hatshepsut kneeling between WertHekau and Khnum, ${ }^{33}$ queen smiting captive, queen embraced by Amun, Anukis nursing young Hatshepsut with Amun in palanquin, and Hatshepsut between Atum and Amun. ${ }^{34}$ (Figs. 8- 10)

Plan of Amenhotep tomb, Sheikh Abd el-Quanah (TT. 73)

$$
\text { P. M, I, p. } 136
$$

The most interesting scene in the tomb is that depicting the presentation of the gifts to the queen, presumably on New Year's Day. ${ }^{35}$

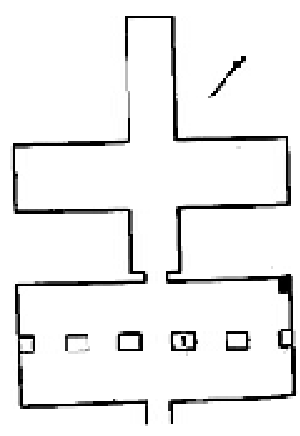

${ }^{30}$ Gardiner, A. and Weigall, A., A Topographical Catalogue of the Private Tombs of Thebes, London: Quaritch, 1913, pp. 22- 23.

31 Säve-Söderbergh, T., Four Eighteenth Dynasty Tombs, Oxford, 1957, p. 1, note. 1.

${ }^{32}$ P. M, I, p. 143 (3).

33 Säve-Söderbergh, T., Four Eighteenth Dynasty Tombs, Private Tombs at Thebes, 1, Oxford, 1957, pl. iii.

${ }^{34}$ P. M, I, p. 143.

35 Helck, W., Der Einfluss der Militärführer in der 18. ägyptischen Dynastie, Leipzig 1939, p. 48; and tomb Nos. 48, 76, 92, 93, 96, 100. 


\subsection{Tomb of Thenuna, Sheikh Abd el-Quanah, Tuthmosis IV (TT. 76):}

He was fan-bearer on the right of the king. ${ }^{37}$ There is a scene for New Year gifts including [gold statuettes of Tuthmosis IV censing before himself and his mother queen Teye]. ${ }^{38}$ (Fig. 11)

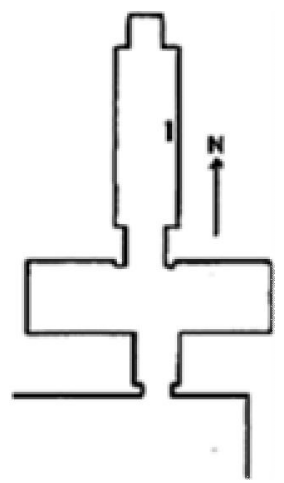

Plan of Thenuna tomb, Sheikh Abd el-Quanah (TT. 76)

P. M, I, p. 148

${ }^{36}$ Kampp, F., Die Thebanische Nekropole. Zum Wandel des Grabgedankens von der XVIII. bis zur XX. Dynastie, Theben, 13, 2 vols, Mainz am Rhein: Verlag Philipp von Zabern, 1996, pp. 312- 313, fig. 199.; Gardiner, A. and Weigall, A., A Topographical Catalogue of the Private Tombs of Thebes, London: Quaritch, 1913, pp. 22- 23.

${ }^{37}$ P. M, I, p. 149 (5); Gardiner, A. and Weigall, A., A Topographical Catalogue of the Private Tombs of Thebes. London: Quaritch, 1913, pp. 22-23.

${ }_{38}$ P. M, I, p. 150; Säve-Söderbergh, T., Four Eighteenth Dynasty Tombs, Private Tombs at Thebes, 1, Oxford, 1957. pp. 50- 52, pl. lxxii, fig. 1. 
5. Other New Year festival:

5.1 Tomb of Amenemheb, Sheikh Abd el-Quanah, Tuthmosis III Amenhotep II (TT. 85): $:^{39}$

He was Lieutenant commander of

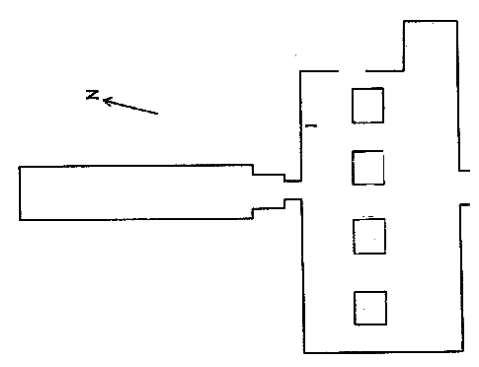
soldiers during the $18^{\text {th }}$ dynasty. He called "Mahu", commander of soldiers. His wife called as Baki (Chief royal nurse), while his mother known as "Tetires".

Tomb of Amenemheb, Sheikh Abd el-Quanah (TT. 85)

P. M, I, p. 160

There is a scene on pillar 'No. 1', for the deceased that offers bouquet of Amun at New Year festival to wife suckling young prince with another scene for the deceased adoring with hymn to Tuthmosis III. ${ }^{40}$

\subsection{Tomb of Menkheperraseneb, Sheikh Abd el-Quanah, Tuthmosis III (TT. 86): ${ }^{4}$}

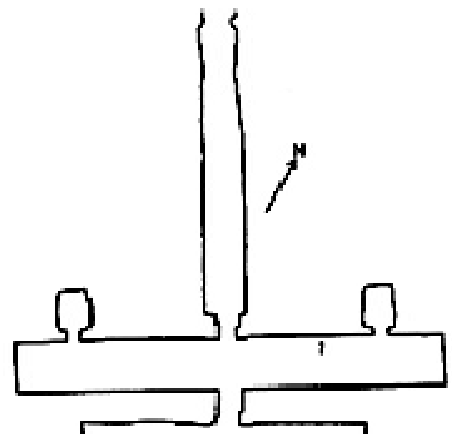

He was high priest of Amun, superintendent of the gold and silver treasuries, and chief of the overseers of craftsmen. ${ }^{42}$

Plan of Menkheperraseneb tomb, Sheikh Abd el-Quanah (TT. 86)

P. M, I, p. 176

39 Eisermann, S., Die Gräber des Imenemhet und des Pehsucher-Vorbild und Kopie?, In, Thebanische Beamtennekropolen: Neue Perspektiven archäologischen Forschung, SAGA, 12, Assmann. J., Dziobek, E., Guksch, H., and Kampp, F., (eds), Heidelberg, 1995, pp. 6580; Gardiner, A. and Weigall, A., A Topographical Catalogue of the Private Tombs of Thebes, London: Quaritch, 1913, pp. 24- 25; Gnirs, A., Grothe E., and Heike Guksch, H., Zweiter Vorbericht über die Aufnahme und Publikation von Gräbern der 18. Dynastie der thebanischen Beamtennekropole, MDAIK, 53, 1997, pp. 57- 83.

${ }^{40}$ P. M, I, p. 173

41 Dorman, P., Two Tombs and One Owner, In, Thebanische Beamtennekropolen: Neue Perspektiven archäologischen Forschung, Assmann, J., Dziobek, E., Guksch, H., and Kampp, F., (eds), SAGA, 12, Heidelberg, 1995, pp. 141- 154.

${ }^{42} \mathrm{He}$ is also owner of tomb (TT. 112), P. M, I, pp. 229- 230. 
There is a scene for king Tuthmosis III in the kiosk and the owner of the tomb with four rows of decorative vases (including floral vases with frog and pigeon) offering bouquet of Amun to him at New Year festival, also there is a northern tribute. ${ }^{43}$

\subsection{Tomb of Nakht, Dra' Abu el-Naga', Amenhotep III (TT. $161):^{44}$}

He was bearer of floral offerings of Amun, during the reign of Amenhotep III. His parents; Guraru and Kay, and his wife: Tahemt. ${ }^{45}$

Plan of Nakht tomb, Dra' Abu el-Naga' (TT. 161)

P. M, I, p. 272

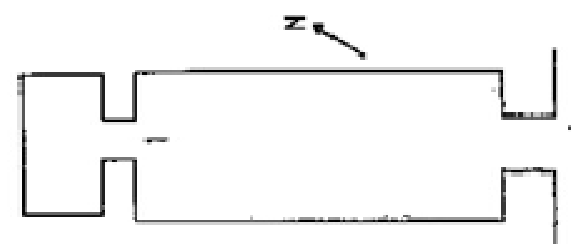

On the entrance of the shrine, left of the doorway, there is a stela. Above the stela, deceased offers bouquet to the reigning king Tuthmosis III on the occasion of the New Year. ${ }^{46}$ (Fig. 12)

${ }^{43}$ Davies, Nina de Garis and Norman de Garis Davies, The Tombs of Menkheperrasonb, Amenmose, and Another (nos. 86, 112, 42, 226), TTS, 5, London: EES, 1933, pls.iii- vii; Engelmann von Carnap, B., Die Struktur des thebanischen Beamtenfriedhofs in der ersten Hälften der 18. Dynastie: Analyse von Position, Grissgestaltung und Bildprogramm der Gräber, ADAIK, Agyptologische Reihe, 15, Berlin, 1999. pp. 124- 131, pl. 35.

44 Kampp, F., Die Thebanische Nekropole, Zum Wandel des Grabgedankens von der XVIII. bis zur XX. Dynastie, Theben, 13, vol. 1, Verlag Philipp von Zabern, Mainz am Rhein, 1996, pp. 451- 452, fig. 345; La tombe de Nakht, Musées Royaux d'Art et d'Histoire, Brüssel, Bruxelles: Musées Royaux d'Art et d'Histoire, 1972, Guides du Département Égyptien, 1; Werbrouck, M., et De Walle, B., La Tombe de Nakht, Notice Sommaire, BMRAH, 3, 1, 1929, pp. 58-61; Wasmuth, M., Innovation und Extravaganzen: Ein Beitrag zur Architektur des Thebanischen Beamtengräber der 18. Dynastie, BAR International Series, 1165, Oxford: British Archaeological Reports, 2003, p. 119.

${ }^{45}$ P. M, I, p. 274; there are many hieratic graffiti were found in this tomb, for more See, Quirke, S., The Hieratic Texts in the Tomb of Nakht the Gardener, at Thebes, no. 161, as Copied by Robert Hay, JEA, 72, 1986, pp. 79-90.

${ }^{46}$ P. M, I, p. 275; Manniche, L., The Tomb of Nakht, the Gardener, at Thebes (No. 161) as Copied by Robert Hay JEA, 72, 1986, p. 58. 


\section{دراسات في آثار الوطن العربي 1}

\section{Conclusion:}

Finally, the tombs showing the deceased receives New Year gifts are in various parts of the Theban necropolis: Sheikh Abd el-Qurna, El-Khokha. There date either to the one from Middle Kingdom, and ten from New Kingdom period (all of them from $18^{\text {th }}$ dynasty and one was stolen after that in the $22^{\text {nd }}$ dynasty but the scene of the New Year gift was related to the original owner of the tomb from the $18^{\text {th }}$ dynasty).

\begin{tabular}{|c|c|c|c|c|c|}
\hline & Tomb owner & Tomb place & King Name & TT. & $\begin{array}{l}\text { Place of } \\
\text { Scene }\end{array}$ \\
\hline \multirow{4}{*}{$\begin{array}{l}\text { New Year gifts } \\
\text { before deceased } \\
\text { and his wife }\end{array}$} & Puimre & El-Khokha & Thutmose III & 39 & $\begin{array}{l}\text { South chapel } \\
\text { (right/ left } \\
\text { wall) }\end{array}$ \\
\hline & Intefiqer & \multirow[b]{4}{*}{$\begin{array}{l}\text { Sheikh Abd } \\
\text { el-Qurna }\end{array}$} & $\begin{array}{c}\text { Amenemhat I } \\
\text { and Senwosret } \\
\text { I }\end{array}$ & 60 & Passage \\
\hline & Amenhotep & & Thutmose I & 345 & Hall \\
\hline & Na'amutnakht & & $22^{\text {nd }}$ dynasty & 348 & Court \\
\hline $\begin{array}{l}\text { New Year gifts } \\
\text { from wife and all } \\
\text { of the family to } \\
\text { the deceased }\end{array}$ & Senneferi & & Tuthmosis III & 99 & $\begin{array}{l}\text { Pillar of the } \\
\text { passage }\end{array}$ \\
\hline $\begin{array}{l}\text { New Year gifts } \\
\text { from a person to } \\
\text { the deceased }\end{array}$ & Mentiywy & El-Khokha & $\begin{array}{l}\text { Tuthmosis III- } \\
\text { Amenhotep II }\end{array}$ & 172 & Passage \\
\hline \multirow{2}{*}{$\begin{array}{l}\text { Other New Year } \\
\text { gifts }\end{array}$} & Amenhotep & \multirow{4}{*}{$\begin{array}{l}\text { Sheikh Abd } \\
\text { el-Qurna }\end{array}$} & Hatshepsut & 73 & Hall \\
\hline & Thenuna & & Tuthmosis IV & 76 & Hall \\
\hline \multirow[t]{3}{*}{$\begin{array}{l}\text { Other New Year } \\
\text { festival }\end{array}$} & Amenemheb & & $\begin{array}{l}\text { Tuthmosis III } \\
\text { Amenhotep II }\end{array}$ & 85 & Pillar \\
\hline & $\begin{array}{l}\text { Menkheperrase } \\
\text { neb }\end{array}$ & & Tuthmosis III & 86 & Hall \\
\hline & Nakht & $\begin{array}{l}\text { Dra' Abu el- } \\
\text { Naga' }\end{array}$ & Amenhotep III & 161 & $\begin{array}{c}\text { Stela } \\
\text { (entrance of } \\
\text { the shrine) }\end{array}$ \\
\hline
\end{tabular}

Deceased receives New Year gifts in Theban Private Tombs 
In conclusion, the New Year gift scenes of all type, as have been represented, not limited with same area, not confined in the same place inside the tomb, they are occupy many and different wall in the tombs as we see three times on the hall of the tomb (TT. 73, TT. 76, TT. 345), two on the passage (TT. 60, TT. 172), one on the pillar (TT. 99), and one on the court (TT. 39)and also on the tomb's chapel (TT. 348).

Also there is a scene for the New Year festival in these private tombs; once depicted on the hall (TT. 86), one on the pillar of the hall (TT. 85 ) and finally on a stela on the entrance of the shrine (TT. 161). 


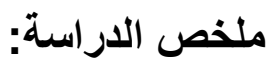

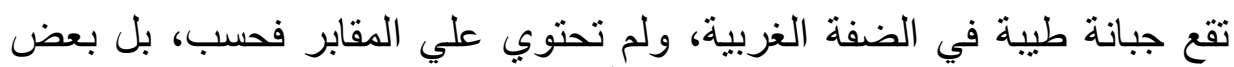

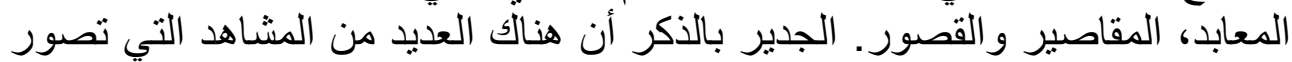

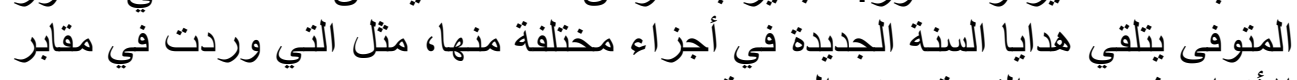

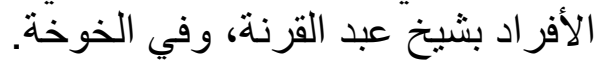

و هنا يمكن للمرء أن يتساءل لماذا وجدت العديد من هذه المشاهد في مقابر أفر اد

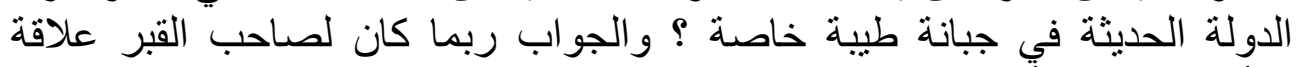

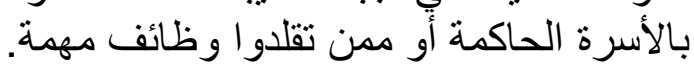

وتأمل هذه الورقة البحثية في الوصول إلي حصر مناظر تمثيل المتوفى وهو

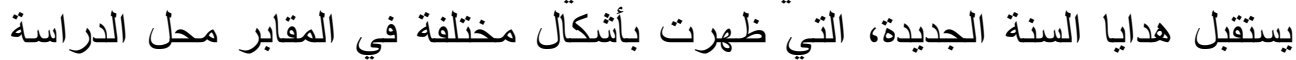

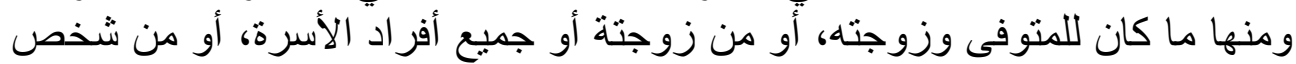

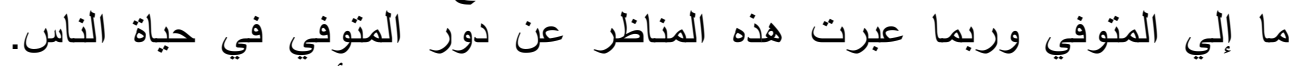

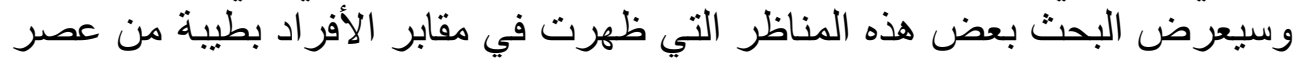

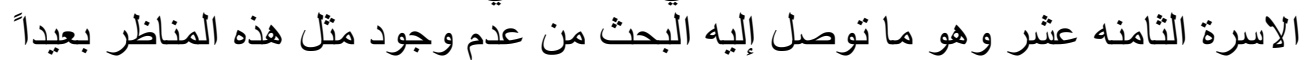
عن هذه الأسرة. 


\section{List of Figures:}

Fig (1): Puimre and his wife Tanefert with New Year gifts, (south) right wall, south chapel (TT. 39), Davies, Norman de Garis, The tomb of Puyemrê at Thebes, II, The chapels of hope, New York, 1923, pl. lviii

Fig (2): Puimre and his wife Sensonb with New Year gifts, (north) left wall, south chapel (TT. 39), Davies, Norman de Garis, The tomb of Puyemrê at Thebes, II, The chapels of hope, New York, 1923, pl. lviii

Fig (3): Intefiqer and his wives inspect four registers of New Year gifts, north wall (TT. 60), Davies, Norman de Garis, The Tomb of Antefoker, Vizier of Sesostris I and of His Wife, Senet (No. 60), TTS, 2, London: EES, 1920, pl. xiv

Fig (4): The gifts of the New Year, north wall (TT. 60), Davies, Norman de Garis, The Tomb of Antefoker, Vizier of Sesostris I and of His Wife, Senet (No. 60), TTS, 2, London: EES, 1920, pl. x

Fig (5): The gifts of the New Year, north wall (TT. 60), Davies, Norman de Garis, The Tomb of Antefoker, Vizier of Sesostris I and of His Wife, Senet (No. 60), TTS, 2, London: EES, 1920, pl. xiii

Fig (6): Owner of the tomb receives New Year gifts from his wife and his family with remains of texts.

Fig (7): Owner of the tomb receives New Year gifts from his wife and his family with remains of texts.

Fig (8): North west wall, left part, Säve-Söderbergh, T., Four Eighteenth Dynasty Tombs, Private Tombs at Thebes, 1, Oxford, 1957, pl. ii

Fig (9): Hatshepsut kneeling between Sekhmet and Amun (TT. 73), SäveSöderbergh, T., Four Eighteenth Dynasty Tombs, Private Tombs at Thebes, 1, Oxford, 1957, pl. iii

Fig (10): Hatshepsut kneeling between Wert-Hekau and Khnum (TT. 73), SäveSöderbergh, T., Four Eighteenth Dynasty Tombs, Private Tombs at Thebes, 1, Oxford, 1957, pl. iii

Fig (11): New Year gifts [gold statuettes of Tuthmosis IV censing before himself and his mother queen Teye] (TT. 76), Säve-Söderbergh, T., Four Eighteenth Dynasty Tombs, Private Tombs at Thebes, 1, Oxford, 1957. pp. 50-52, pl. lxxii.

Fig (12): Left of doorway, above stela, Nakht offers bouquet to Tuthmosis III, La tombe de Nakht, Musées Royaux d'Art et d'Histoire, Brüssel, Bruxelles: Musées Royaux d'Art et d'Histoire, 1972, Guides du Département Égyptien, 1, p. 16 
دراسات في آثار الوطن العربي؟ 1

Figures:

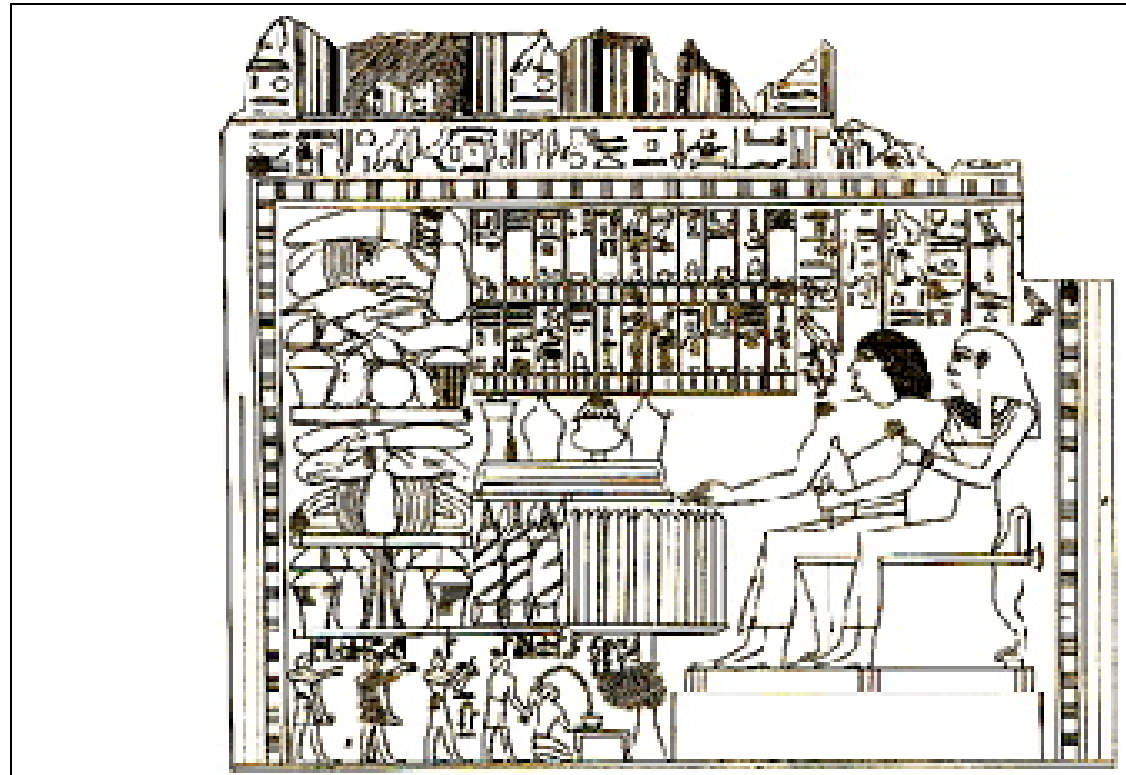

Fig (1): Puimre and his wife Tanefert with New Year gifts, (south) right wall, south chapel (TT. 39)

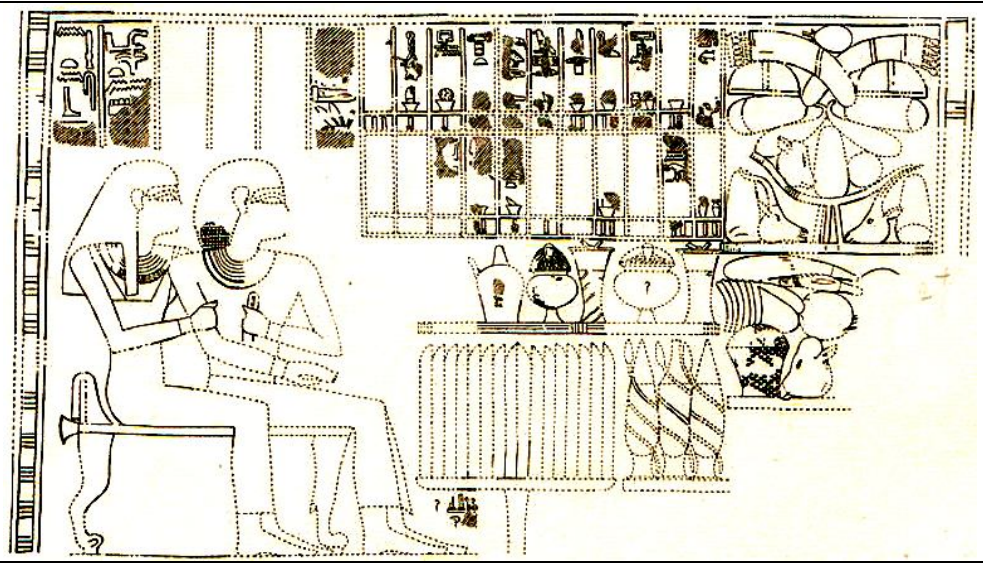

Fig (2): Puimre and his wife Sensonb with New Year gifts, (north) left wall, south chapel (TT. 39) 
Fig (3): Intefiqer and his wives inspect four registers of New Year gifts, north wall (TT. 60)

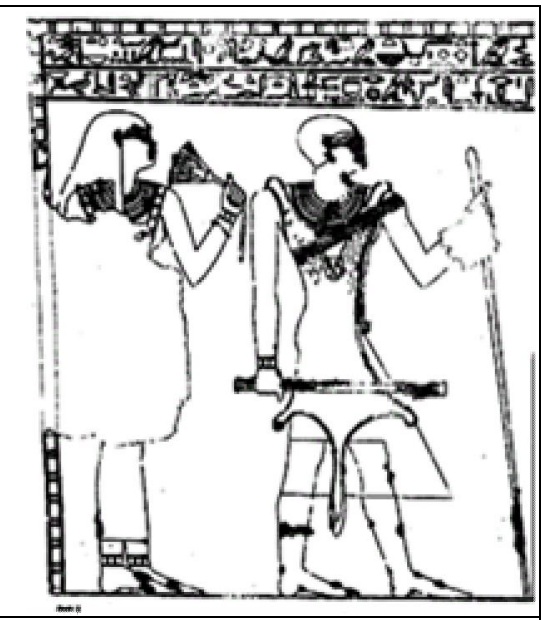

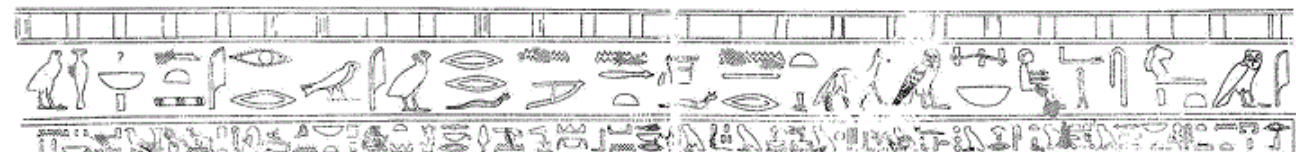

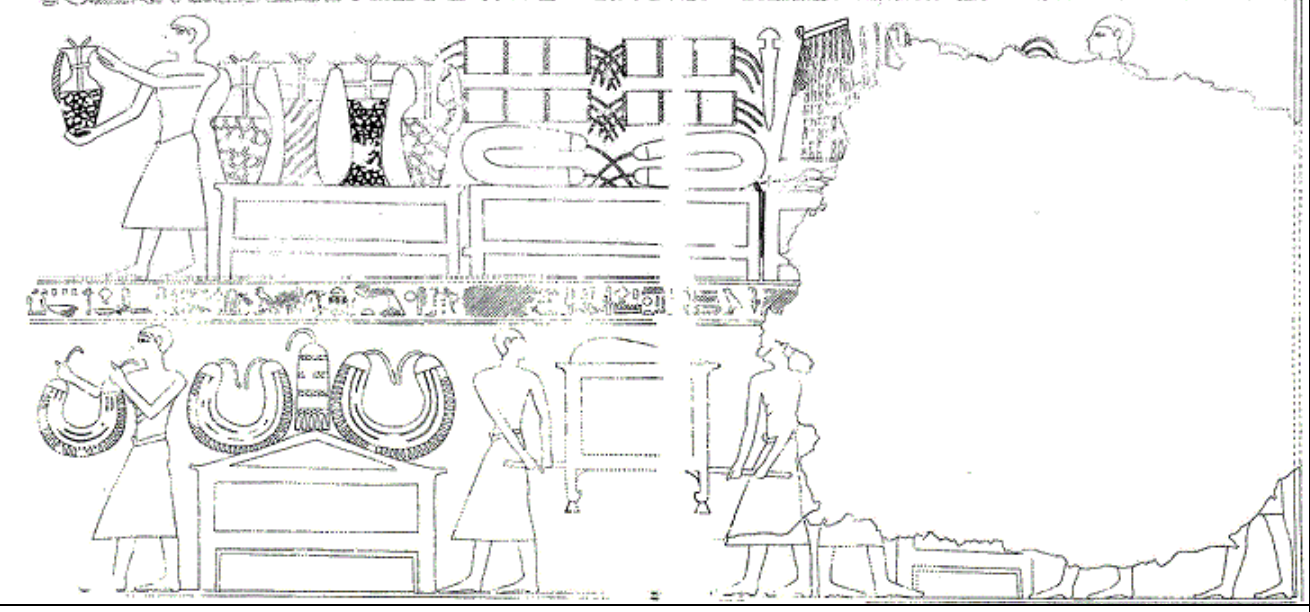

Fig (4): The gifts of the New Year, north wall (TT. 60) 
دراسات في آثار الوطن العربيَ

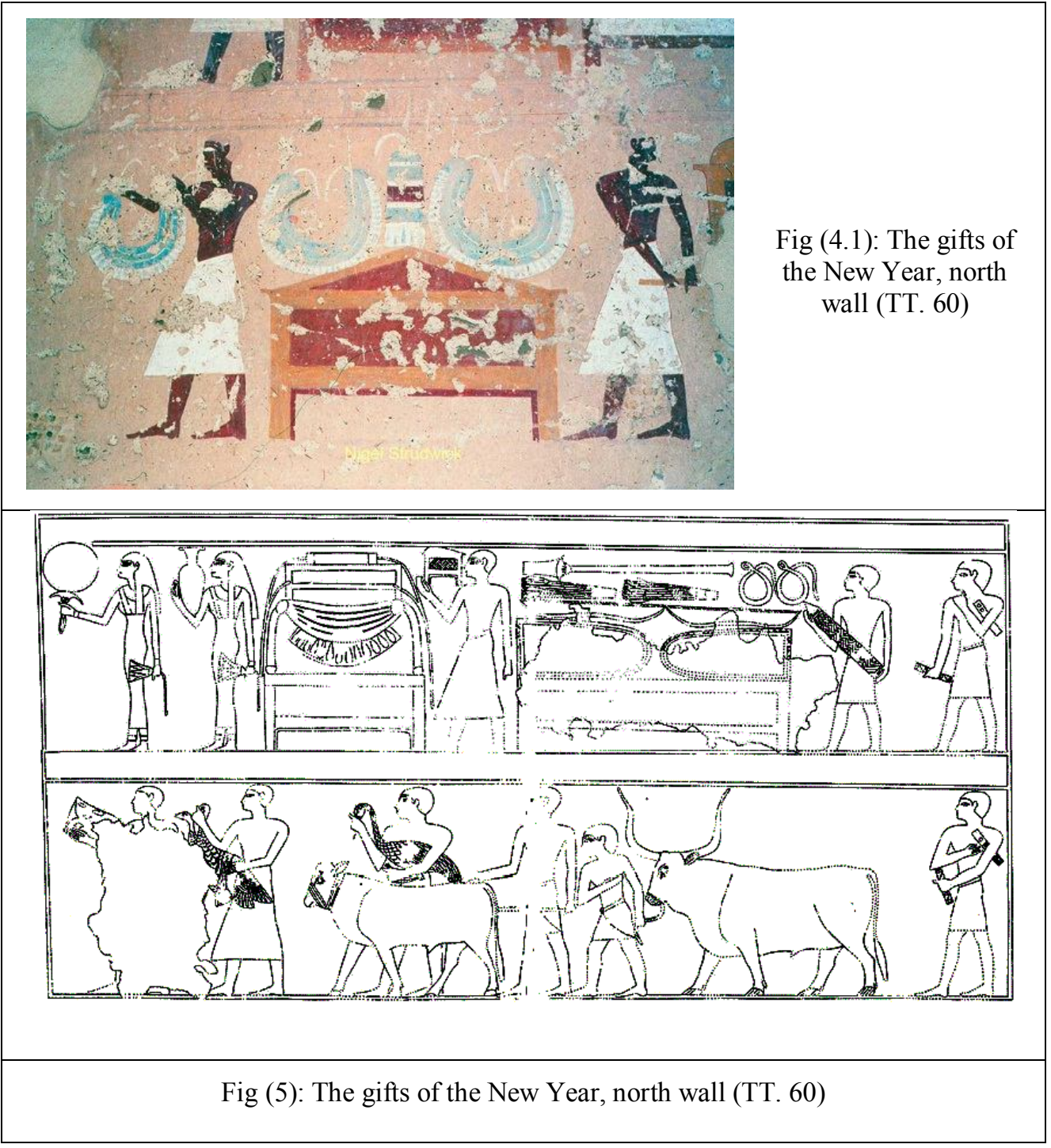


دراسات في آثار الوطن العربي 1

Fig (5.1): The gifts of the New Year, north wall (TT. 60)

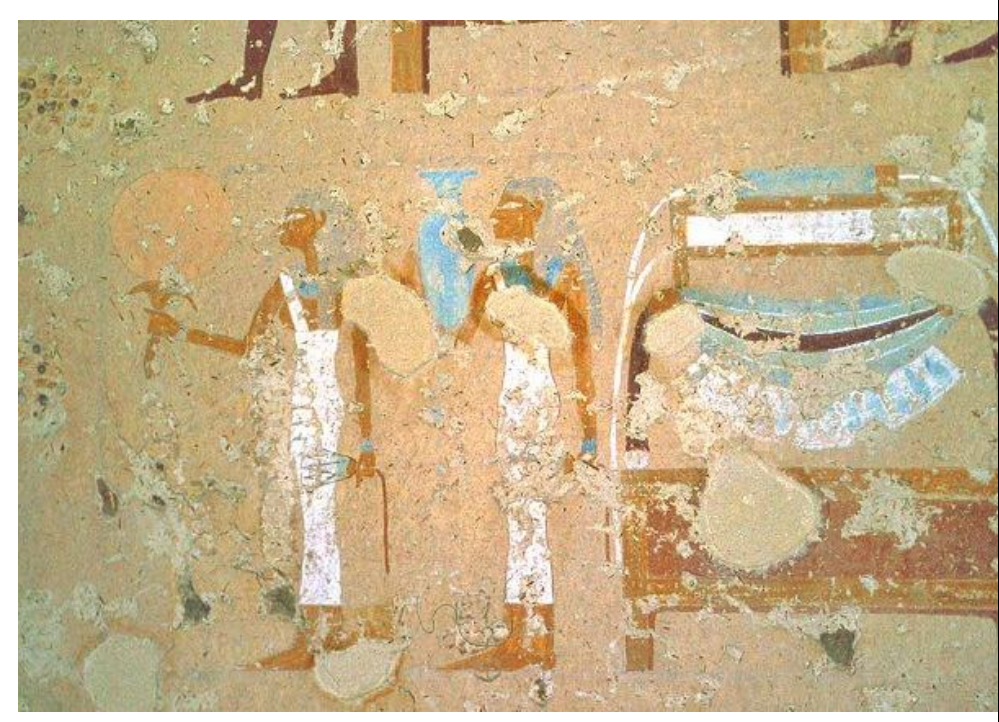

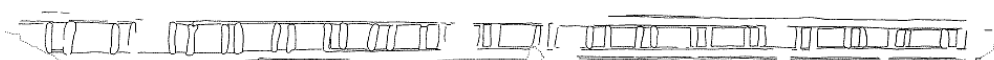
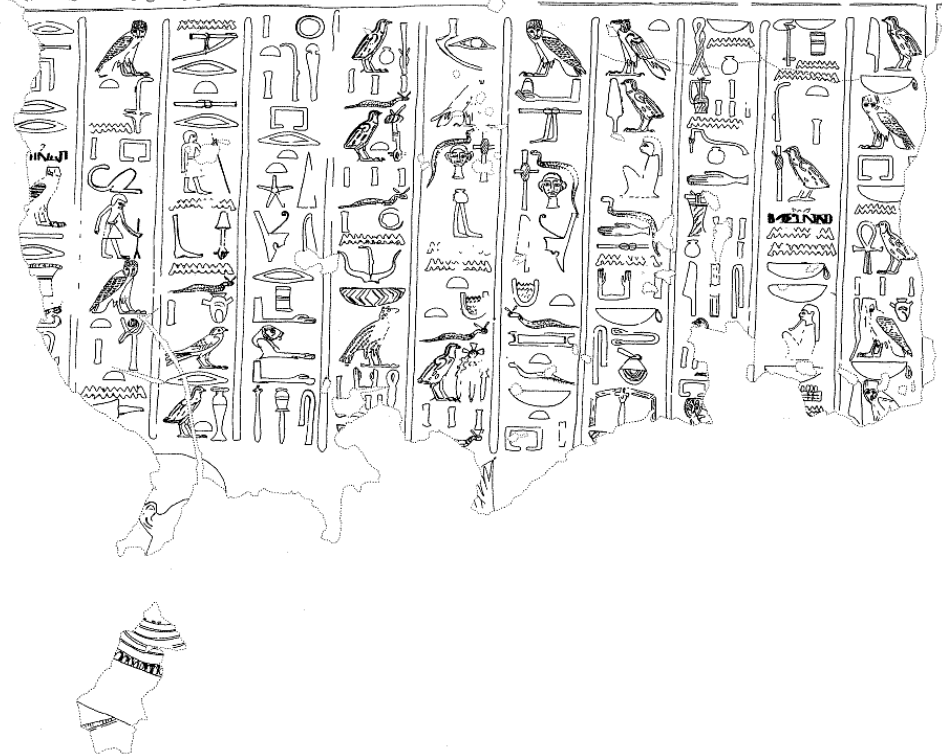

Fig (6): Owner of the tomb receives New Year gifts from his wife and his family with remains of texts. 
دراسات في آثار الوطن العربيَ

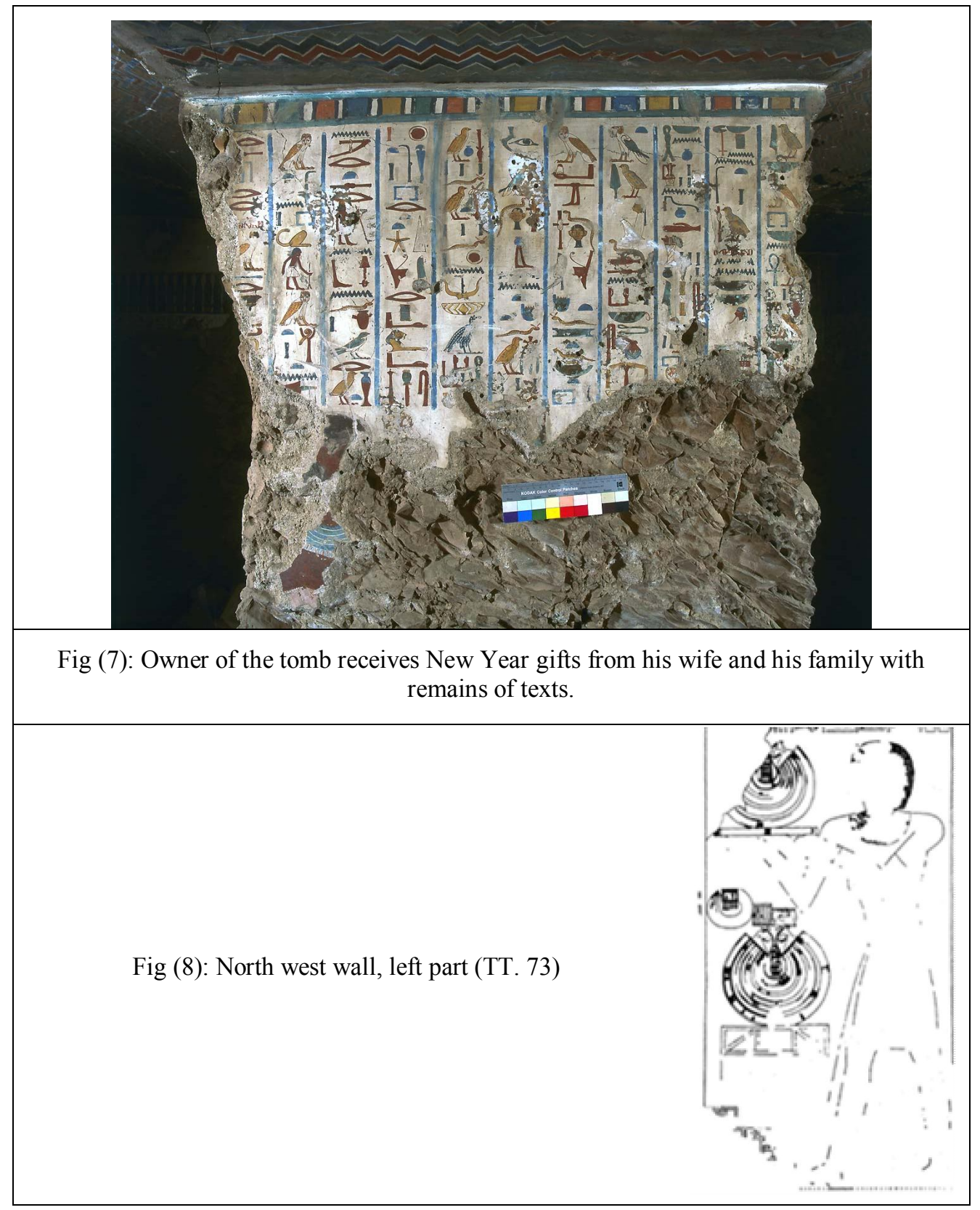


دراسات في آثار الوطن العربيَ'

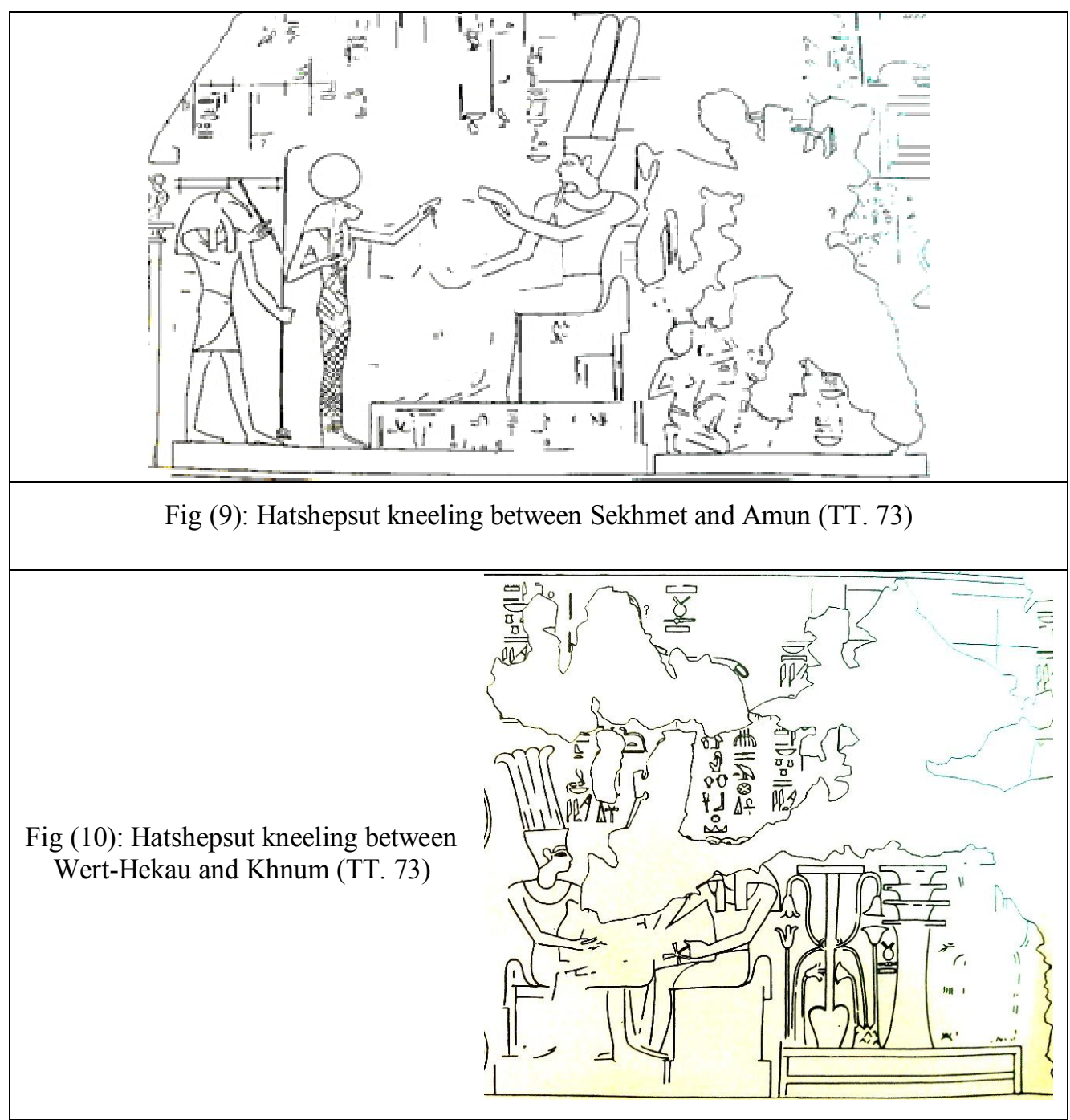




\section{دراسات في آثار الوطن العربي 1}

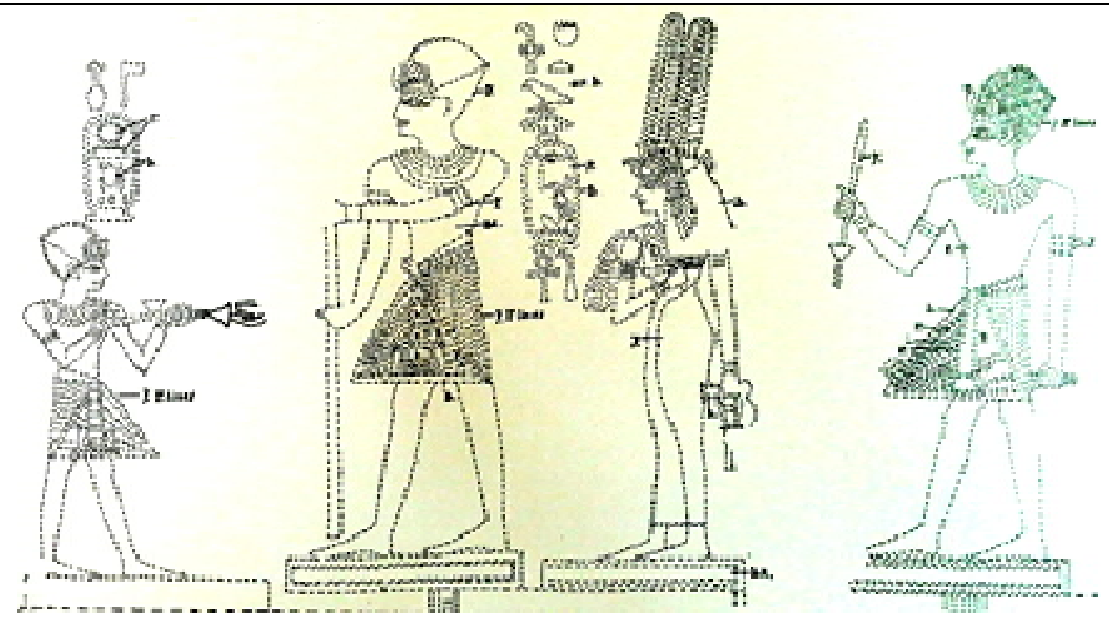

Fig (11): New Year gifts [gold statuettes of Tuthmosis IV censing before himself and his mother queen Teye] (TT. 76)

Fig (12): Left of doorway, above stela, Nakht offers bouquet to Tuthmosis III

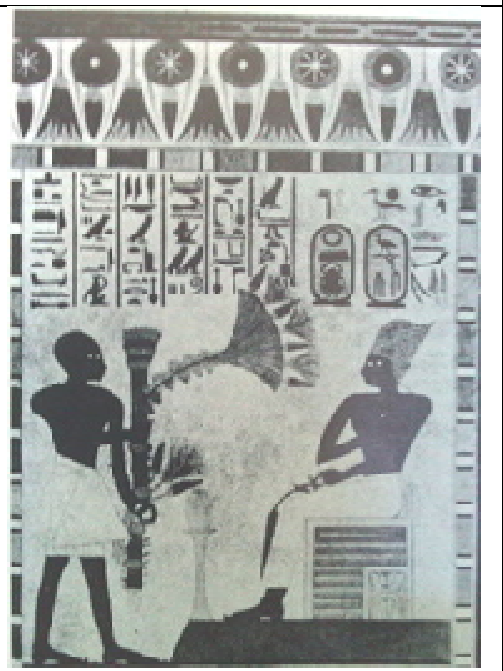

